\title{
Resistance Induction for Meloidogyne incognita in Sugarcane through Mineral Organic Fertilizers
}

\author{
Andréa Chaves $^{1 *}$, Elvira Maria Régis Pedrosa ${ }^{2}$, Rejane Magalhães de Mendonça Pimentel $^{3}$, \\ Rildo Sartori Barbosa Coelho ${ }^{4}$, Lílian Margarete Paes Guimarães ${ }^{4}$ and Sandra Roberta \\ Vaz Lira Maranhão ${ }^{4}$ \\ ${ }^{1}$ Estação Experimental de Cana-de-açúcar do Carpina; Laboratório de Fitonematologia. ${ }^{2}$ Departamento de \\ Tecnologia Rural. ${ }^{3}$ Departamento de Biologia/Área de Botânica; Laboratório de Fitomorfologia Funcional. \\ ${ }^{4}$ Departamento de Agronomia; Universidade Federal Rural de Pernambuco; 52171-90; Recife - PE - Brasil
}

\begin{abstract}
The effects of Coda Radimax (CR), Coda Humus-PK $(\mathrm{CH})$ and Coda Vit $(\mathrm{CV})$ on the induction of resistance for Meloidogyne incognita in sugarcane (Saccharum sp.) varieties (RB92579, RB863129, RB867515) through nematode reproduction, plant development and root anatomy analysis, emphasizing the differences of the lignin deposition, and cortex-vascular cylinder proportions were investigated. In 90 days after inoculation with eggs of $\mathrm{M}$. incognita, $C R$ reduced the number of eggs per root system in all the sugarcane varieties; $C H$ and $C V$ reduced eggs density in RB867515; CR increased stalk number in RB92579 and fresh weight of shoots in RB863129 and RB92579; $C H$ increased plant height in RB92579 and fresh weight of shoots in RB92579 and RB867515, CV affected fresh weigh of shoots and roots of RB863129. All the tested compounds did not affect stalk diameter, number and dry weight of shoots. Cross-sections of roots showed no anatomical changes in the M. incognita inoculated tissues.
\end{abstract}

Key words: Saccharum spp., phosphites, root-knot nematode, root anatomy, Meloidogyne

\section{INTRODUCTION}

In Northeastern Brazil the land use of sandy costal table with sugarcane (Saccharum sp.) cropping associated with high temperatures and long dry seasons have increased plant parasitism nematode, particularly Meloidogyne spp. and Pratylenchus zeae Graham, severity in fields (Moura et al., 2000). Despite many control measures, almost all of them along with systemic nematicides, none has been efficient enough to keep nematode level under economic threshold level (Novaretti et al., 1989; Chaves, Pedrosa and Moura, 2002; Rosa, 2003; Chaves et al., 2004). Therefore, search for more efficient, economic and ecological sound alternatives has been encouraged.

The systemic acquired resistance (SAR) activates the defense mechanisms related to structural barriers, such as cell wall lignifications and antimicrobial compounds synthesis like PR-proteins, peptides and phytoalexins by action of biotic and abiotic elicitors (Oliveira, Dantas and Gurgel, 2004; Silva and Resende, 2001). The SAR is related with the microorganisms (Benato, 2002), while the antimicrobial compounds synthesis deals with the natural and synthetic compounds, which modify the plant-pathogen interaction similarly to an incompatible response (Durrant and Dong, 2004). Under this point of view, phosphites

\footnotetext{
* Author for correspondence: achavesfiuza@yahoo.com.br
} 
$\left(\mathrm{H}_{2} \mathrm{PO}_{3}{ }^{-}\right)$are mineral organic fertilizers (Cohen and Coffey, 1986) which activate defense mechanisms in plants (Jackson et al., 2000), inducing immediate response to pathogen challenge (Guest and Bompeix, 1990). They are highly soluble, promptly assimilated and easily metabolized in the plant (Rickard, 2000). This salt of phosphorous acid has been efficient against a range of fungal pathogens such as Plasmopara viticola (Berk. Et Curtis ex de Bary) Berl. et de Toni (Wicks et al., 1990), Venturia inaequalis (Cooke) Wint and Podosphaera leucotricha (Ell. and Ev.) Salmon (Geelen, 1999), Phytophthora parasitica Dastur, Phytophthora citrophtrora (Smith and Smith) Leonian, Phytophthora nicotianae Breda de Hann, Phytophthora infestans (Mont.) de Bary, Phytophthora capsici Leonian, Phytophthora palmivora Butler, Phytophthora cinnamomi Ronds (Hardy, Barret and Shearer, 2001) and Peronospora sparsa Berkeley (Brandão, 2006).

Functional behavior of graminaceous roots have been described for regarding to gas transport in relation to physical barriers in the cortex outer layers (Visser et al., 2000; McDonald, Galwey and Colmer, 2002). Apparently, the influence of the association of the fertilizer and fungi inoculation on mechanical strength and resistance in the root structure has not been addressed. Anatomical features such as extent of aerenchyma, stele dimensions, pattern of cortical cell arrangement, and a barrier to radial $\mathrm{O}_{2}$ loss are important to the efficacy of internal aeration within a root (Armstrong, 1979; Armstrong and Beckett, 1987; McDonald, Galwey and Colmer, 2002). Althougt adaptive value in the proportion of aerenchyma has been observed between different species (Vasellati et al., 2001). The largest survey of the anatomical features of roots of sugarcane focused different aspects as the anatomy, morphology and physiology (Julien, et al. 1988), the adaptation of adventitious roots to waterlogged soils (McDonald, Galwey and Colmer, 2002), deprivation of oxygen in sugarcane under pathogen action (Yin and Hoy, 1998), and the pathogen infecting stalks (Chona, 1950).

Interactions between the plants and parasitic nematodes have been studied, focusing preferentially physiology and molecular aspects (Hussey and Williamson, 1998) without any reference to the possible disturbances in the anatomical structure in the new roots produced by infected plants. The objective of this study was to investigate the effects of mineral organic complexes on the induction of resistance to Meloidogyne incognita (Kofoid and White) Chitwood, 1949 in sugarcane varieties through nematode reproduction, plant development and root anatomy analysis. The differences of the lignin deposition and both cortex and vascular cylinder proportions were emphasized.

\section{MATERIALS AND METHODS}

Two months old seedlings from meristem culture of sugarcane varieties (RB92579, RB863129 and RB867515) were grown under greenhouse (temperature range 30 to $35^{\circ} \mathrm{C}$ ) and each seedling was planted in 5L-pot filled with soil, previously fumigated with methyl bromide. Twenty days after the planting, seedlings had the soil sprayed with the organic-mineral fertilizers Coda Humus-PK (20 L/ha), Coda Radimax (3 L/ha) and Coda Vit (5 $\mathrm{L} / \mathrm{ha}$ ), and the controls was pulverized with water. The pots was arranged in a completely randomized design in a $4 \times 3$ factorial scheme with four replications on greenhouse bench. $M$. incognita inoculum was obtained according to Hussey and Barker (1973) and soil was infested with 5000 eggs per plant at five days after fertilizer application. For evaluation, plants were left to grow for 90 days after inoculation. Data collected included plant height, shoots and stalk number, stalk diameter, dry weight of shoots, fresh weight of shoots and roots, and gall index (Taylor and Sasser, 1978). Nematode reproduction was assessed through the number of eggs per root system, collected from whole root system with $1 \%$ $\mathrm{NaOCl}$ (Hussey and Barker, 1973) and counted under a stereomicroscope.

For statistical analysis, nematode population data (x) were transformed to $\log _{10}(x+1)$ values, and reported as antilogs. Analysis of variance was conducted for number of eggs in root systems, plant height, shoots and stalk number, stalk diameter, fresh weight of shoots and roots, and dry weight of shoots. Means of variables were compared by orthogonal contrasts.

For the root anatomy analysis, all root sections were gently washed free of soil. Samples were fixed in formalin, acetic acid, ethanol and water (5:5:45:45). Cross-sections were hand cut $2-5 \mathrm{~cm}$ from root tips with a razor blade and stained with safranin and astra blue $1 \%$ one minute (Krauter, 1985). Comparisons made for each root section 
(five per treatment) included stain color intensity in wall cell of metaxylem, fiber, endoderm and exoderm. The lignin deposition was evaluated by subjective visual rating for root red color intensity caused by a result of the interaction between substances and the nematode action over the wall cell formation.

From each treatment, 10 hand sections of the root apex (primary structure) were randomly selected to be photographed. Digital images of the cross sectional area of the cortex, vascular cylinder, diameter of inner metaxylem vessels (cell wall not included; Carlquist, 1990), and whole root were taken using an optical microscope (Olympus), connected to a digital camera (Sony) and analyzed with a digital image program, Image Tool (Wilcox et al., 2002). All images were photographed $24 \mathrm{~h}$ after the hand cutting to minimize possible the differences in the coloring. In four replications from each treatment, thickness of the cortex, diameter of the vascular cylinder, and number of metaxylem vessels were selected to be analysed under an optical microscope (Olympus).

Total number of late metaxylem vessels (LMX) per root and their diameters were determined with a microscope. Total number of vessels in five root sections was calculated by multiplying the mean number of LMX vessels per root transverse area. Vessel area was calculated as the sum of areas of all vessels based on the vessel radius, $r$. Relative capacities to deliver solutions was calculated as or 4 (Frensch and Steudle, 1989). For anatomical observations, root sections were stained by safranin and astra blue and observed under an optical microscope (Olympus).

In all the plants, root diameters were similar between control and flooded treatments. During measurement, the root system was not separated from the shoot. All sections were examined under a light microscope (Olympus) and digital images were taken with a digital camera coupled on the microscope. All slices were screened for the presence of a differential colorization of lignified wall from vascular tissue, endodermis and exodermis cells.

\section{RESULTS AND DISCUSSION}

All varieties were good host to $M$. incognita, allowing free nematode reproduction (table. 1) resulting in reproductive factors $(\mathrm{RF}=\mathrm{Pf} / \mathrm{Pi})$ higher than 1. In contrast, all plants treated with Coda Radimax decreased nematode reproduction as well reproductive factors lower than 1. Compared to the untreated control, Coda Radimax significantly decreased final number of eggs per root system in all the varieties (table. 2). However, the plant response to Coda Humus-PK and Coda Vit depended on sugarcane variety. Coda Humus-PK and Coda Vit were efficient in reducing eggs density in RB867515 but not in RB863129 (table. 2). Adult females with egg mass were found in the galls; however, in plants with Coda Radimax low number of juveniles were able to complete the life cycle, possibly the second stage juveniles penetrated the roots, injected secretions inducing gall formation but few were able to efficiently produce feeding sites (Pedrosa et al., 1996; Maciel and Ferraz, 1996).

All tested compounds did not affect stalk diameter, and dry weight and number of shoots (table. 3). Coda Radimax significantly increased stalk number in RB92579 and fresh weight of shoots in RB863129 and RB92579. Coda Humus-PK significantly increased plant height in RB92579 and fresh weight of shoots in RB92579 and RB867515 while Coda Vit significantly affected the fresh weigh of both shoots and roots of RB863129.

Table 1 - Reproduction factor $(\mathrm{RF}=\mathrm{Pf} / \mathrm{Pi})$ of Meloidogyne incognita and root gall index (GI) in sugarcane (Saccharum sp.), 90 days after inoculation.

\begin{tabular}{ccccccccccc}
\hline \multirow{2}{*}{ Fertilizer } & \multicolumn{3}{c}{ RB863129 } & \multicolumn{3}{c}{ RB94579 } & \multicolumn{3}{c}{ RB867515 } \\
\cline { 2 - 10 } & RF & GI & Reaction & RF & GI & Reaction & RF & GI & Reaction \\
\hline Coda Humus-PK & 2.60 & 3.0 & $\mathrm{~S}$ & 3.96 & 3.0 & $\mathrm{~S}$ & 0.54 & 2.0 & $\mathrm{R}$ \\
Coda Radimax & 0.72 & 2.0 & $\mathrm{R}$ & 0.81 & 2.0 & $\mathrm{R}$ & 0.63 & 2.0 & $\mathrm{R}$ \\
Coda VIT & 16.77 & 3.0 & $\mathrm{~S}$ & 2.99 & 3.0 & $\mathrm{~S}$ & 2.51 & 3.0 & $\mathrm{~S}$ \\
Testemunha & 8.30 & 3.0 & $\mathrm{~S}$ & 7.89 & 3.0 & $\mathrm{~S}$ & 8.04 & 3.0 & $\mathrm{~S}$ \\
\hline
\end{tabular}

*IR=resistant; $\mathrm{S}=$ susceptible. 
Table 2 - Effect of mineral organic fertilizers on number of Meloidogyne incognita eggs in sugarcane roots and the number of galls.

\begin{tabular}{lcccccc}
\hline \multirow{2}{*}{ Contrast } & \multicolumn{7}{c}{ Significance level } \\
\cline { 2 - 7 } & \multicolumn{2}{c}{$\mathbf{R B 8 6 3 1 2 9}$} & \multicolumn{2}{c}{ RB92579 } & \multicolumn{2}{c}{ RB867515 } \\
\cline { 2 - 7 } & Egg & Gall & Egg & Gall & Egg & Gall \\
\hline Coda Radimax $\times$ control & 0.0017 & 0.0497 & 0.0001 & 0.0553 & $<0.0001$ & 0.0471 \\
Coda Humus-PK $\times$ control & 0.2412 & 0.5355 & 0.0923 & 0.0259 & $<0.0001$ & 0.1431 \\
Coda Vit $\times$ control & 0.5197 & 0.0888 & 0.0225 & 0.0175 & 0.0054 & 0.4033 \\
CV $(\%)$ & 8.52 & 14.30 & 5.67 & 9.62 & 5.80 & 26.41 \\
\hline
\end{tabular}

Table 3 - Effect of mineral organic fertilizers on sugarcane (Saccharum sp.) varieties development.

\begin{tabular}{|c|c|c|c|c|c|c|c|}
\hline \multirow[b]{2}{*}{ Contrast } & \multicolumn{7}{|c|}{ Significance level } \\
\hline & $\begin{array}{l}\text { Plant } \\
\text { Height }\end{array}$ & $\begin{array}{c}\text { Stalk } \\
\text { number }\end{array}$ & $\begin{array}{c}\text { Stalk } \\
\text { diameter }\end{array}$ & $\begin{array}{c}\text { Shoot } \\
\text { number }\end{array}$ & $\begin{array}{c}\text { Root fresh } \\
\text { weight }\end{array}$ & $\begin{array}{c}\text { Shoot fresh } \\
\text { weight }\end{array}$ & $\begin{array}{c}\text { Shoot dry } \\
\text { weight }\end{array}$ \\
\hline & \multicolumn{7}{|c|}{ RB863129 } \\
\hline Coda Radimax $\times$ control & 0.3702 & 0.4435 & 0.6739 & 0.0892 & 0.5034 & 0.0022 & 0.4837 \\
\hline $\begin{array}{l}\text { Coda Humus-PK } \times \\
\text { control }\end{array}$ & 0.2418 & 0.3115 & 0.4052 & 0.2112 & 0.9041 & 0.0822 & 0.3149 \\
\hline Coda Vit $\times$ control & 0.1245 & 0.7962 & 0.3021 & 0.3115 & 0.0278 & 0.0343 & 0.4759 \\
\hline $\mathrm{CV}(\%)$ & \multicolumn{7}{|c|}{ RB92579 } \\
\hline Coda Radimax $\times$ control & 0.0741 & 0.0114 & 0.2820 & 0.2012 & 0.2820 & 0.0317 & 0.8029 \\
\hline $\begin{array}{l}\text { Coda Humus-PK× } \\
\text { control }\end{array}$ & 0.0237 & 0.2250 & 0.5586 & 0.0826 & 0.5586 & 0.0182 & 0.8865 \\
\hline Coda Vit $\times$ control & 0.7115 & 0.6774 & 0.2383 & 1.0000 & 0.2383 & 0.5924 & 0.4381 \\
\hline \multirow[t]{2}{*}{ CV $(\%)$} & 8.34 & 30.85 & 14.52 & 21.78 & 30.98 & 11.67 & 13.47 \\
\hline & \multicolumn{7}{|c|}{ RB867515 } \\
\hline Coda Radimax $\times$ control & 0.8029 & 0.1773 & 0.5989 & 0.5744 & 0.2997 & 0.9174 & 0.7057 \\
\hline $\begin{array}{l}\text { Coda Humus-PK× } \\
\text { control }\end{array}$ & 0.8865 & 1.0000 & 0.3011 & 0.1089 & 0.2090 & 0.0395 & 0.7998 \\
\hline Coda Vit $\times$ control & 0.4381 & 1.0000 & 1.0000 & 0.2707 & 0.5892 & 0.0542 & 0.6982 \\
\hline CV $(\%)$ & 11.62 & 24.97 & 10.43 & 37.68 & 39.27 & 14.86 & 25.14 \\
\hline
\end{tabular}

Based on viewing cross-sections of the roots for each sugarcane variety under a microscope (Fig. 1), no significant anatomical changes wise related to the tissues arrangement. However, evident visual red color intensity indicated differences in lignin deposition. Variations in the lignification degree in the stele (fibers) and cortex (exoderm cells) were observed in all sugarcane varieties (Figs. 1-24). It was observed that the reduction was gradual, especially in the fibers near the medullar parenchyma in RB92579 (Figs. 1-4), without effects in the exoderm cells (Figs. 5-8). In RB863129, this effect was more evident in the stele (fibers) with Coda Vit (Figs. 9-12); a similar effect that was not observed in the cortex (exoderm) which showed lower lignification with Coda Radimax (Fig. 15). RB867515 (Figs. 17-24) showed an opposite effect to the RB863129 (Figs. 9-16), without apparent variations in the exoderm (Figs. 13-16). All these differences were evaluated when comparing corresponding tissues in healthy plants.

These results suggested that the roots of sugarcane submitted to different inductors indicated a resistance mechanism related to the lignification degree in stele (fibers) and cortex (exoderm cells) 
to the parasite-feeding site. It could be linked to a mechanism of resistance to the entrance of the parasite, considering the exoderm, and to maintain the water conduction into the xylem in the stele, specifically into the vascular bundle.

In the grass, porosity corresponded to an extensive system of lysigenous aerenchyma tissue arranged radially in the root cortex, separated by rows of parenchymatic cells and surrounded by a ring of schlerenchymatic cells in the exodermis. In the dicots, constitutive porosity was related mainly to intercellular air spaces because of the cubic configuration of the cells in the medium and outer cortex, with few lysigenous lacunae. The arrangement of cells in the inner cortex was the "Panicoid" root type, described by Goller (1977) as those with cubical packing of the cells, forming quadrangular intercellular spaces. This feature has been interpreted by Justin and Armstrong (1987) as a tissue strategy to increase the predisposition to form aerenchyma. This is considered a strategy to enhance the oxygenation to these cells when submitted to an oxygen deficit; greater intercellular gaps permit the oxygen accumulation and facility to the gases exchange.

The cross-section of graminaceous roots resembles a bicycle wheel: air spaces are disposed radially, completely surrounded by a ring of schlerenchymatic tissue. Accordingly, the schlerenchymatic tissue appears to bring mechanical protection to the roots, as in other plant tissues (Reich et al. 1991; Niklas 1992; Niklas 1999). The strength of these cells compensates the fragility of a profusion of large spaces between the parenchyma lacunaes into the cortex and avoids damages to the integrity of the root hindering breaks in it. It is more evident in plants submitted to long periods of flooding. In addition, the particular radial alignment of the cells in the root cortex, parallel to the direction of the mechanical forces, might also contribute to enabling the formation of a physically stable structure. This idea was not suggested previously for internal architecture of herbaceous roots, but followed the same reasoning as proposed by Niklas (1999) for thick-walled cells within the leaf base of Chamaedorea, which possessed a remarkable rigidity owing to its special radial configuration.

Information on the pathological anatomy of root tissues from plants treated with resistance inductors is limited. Certainly, little work has been published on the pathological anatomy of the susceptibility of root tissue of sugarcane. Apparently, the functionality of the root tissue was not affected by any treatment with the fertilizers. Consequently, internal root architecture is basically the same among control and treated plants (Fig. 1), allowing maintenance of root strength.

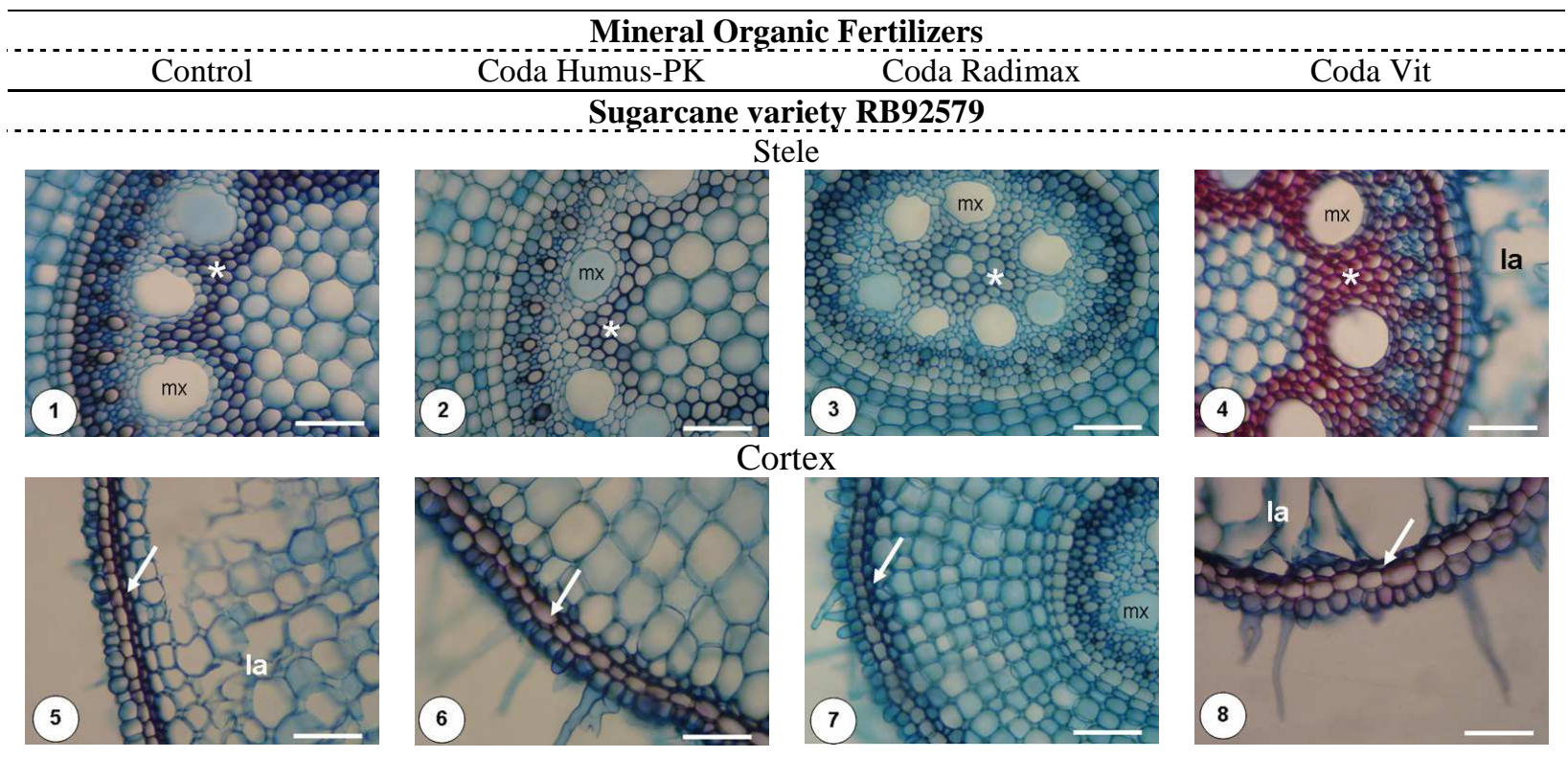


Sugarcane variety RB863129
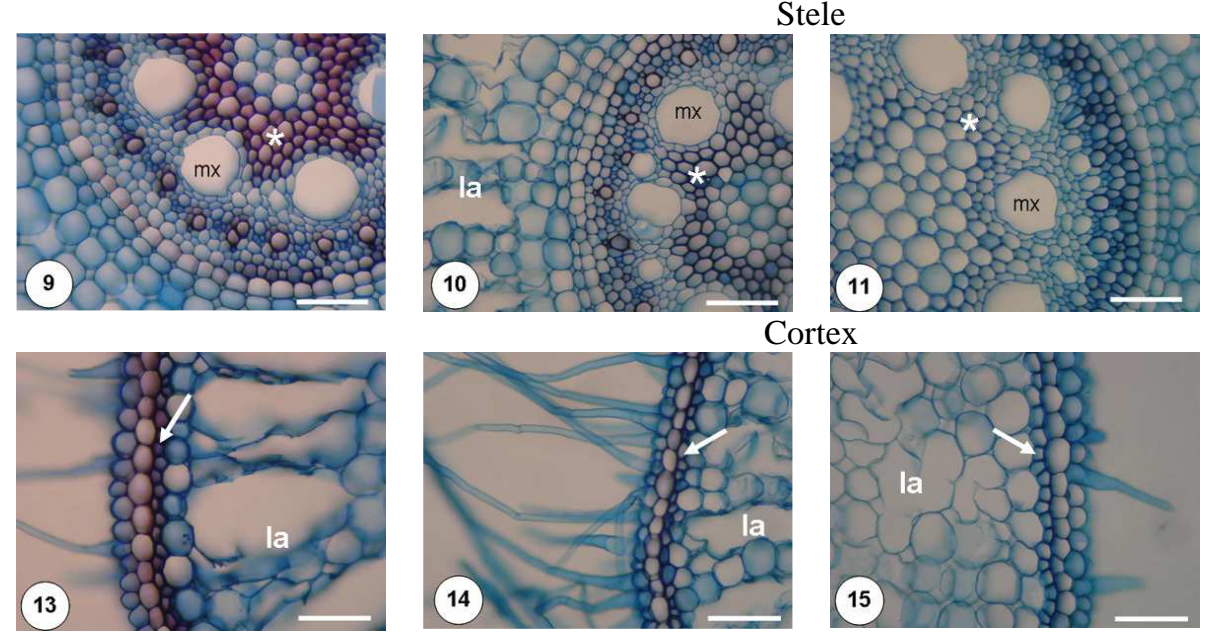

Cortex
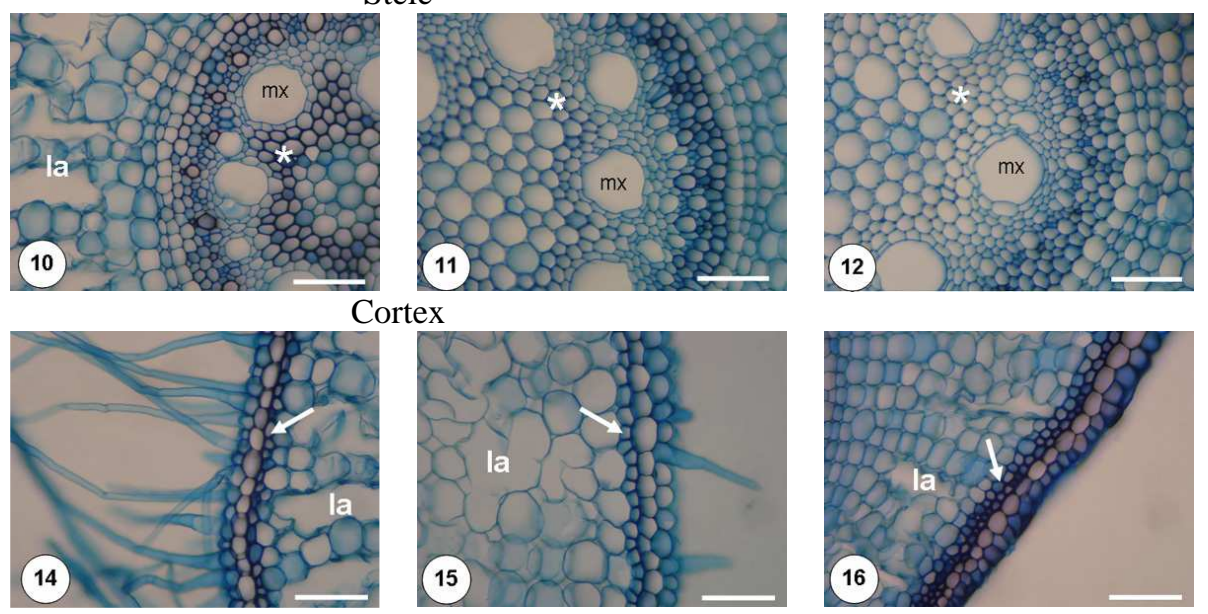

Sugarcane variety RB867515
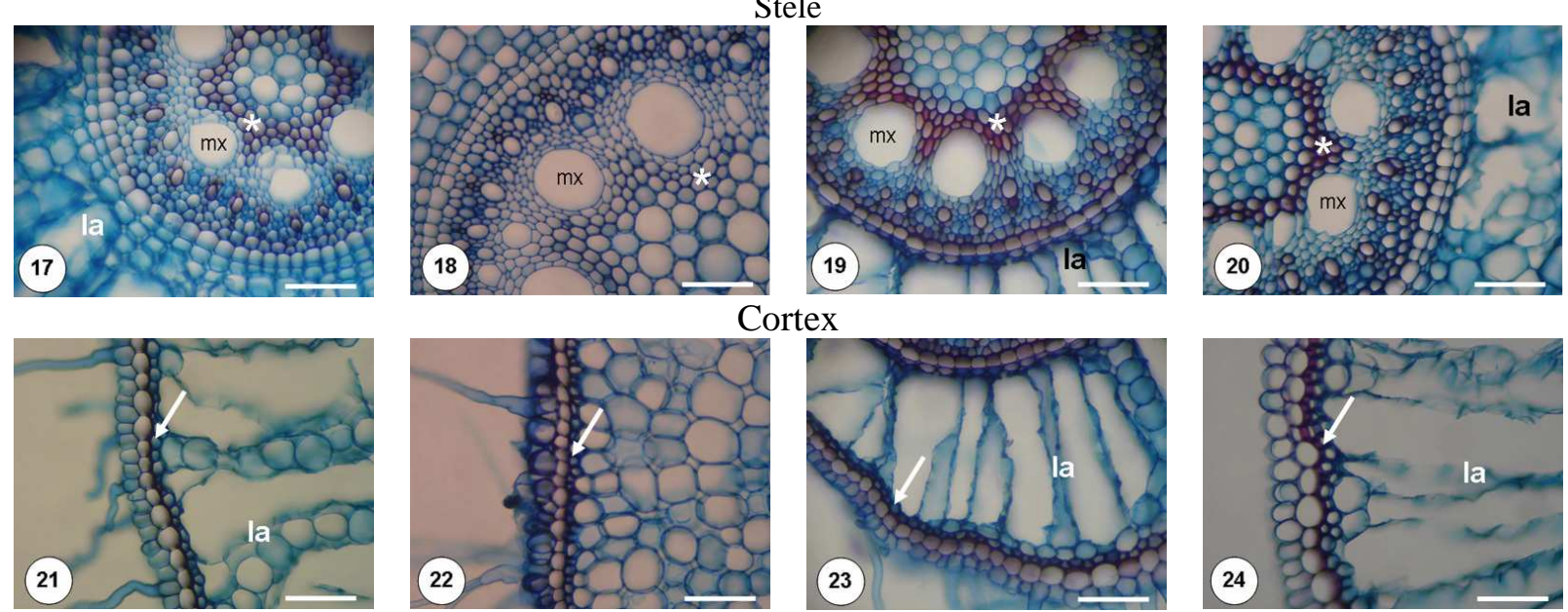

Figures 1-24 - Stele and cortex of sugarcane varieties: 1-8) RB92579, 9-16) RB863129 and 17-24) RB867512 untreated (Control) and submitted to organic mineral fertilizers: Coda Humus-PK, Coda Radimax and Coda Vit. (*) fibers; la=lysigenous aerenchyma; mx=metaxylem; arrow-exoderm. $($ bars $=100 \mu \mathrm{m})$.

\section{RESUMO}

Este estudo investigou, em condições de casa de vegetação, os efeitos de três complexos organo-minerais (Coda Radimax, Coda Humus-PK e Coda Vit) na indução de resistência a Meloidogyne incognita em três variedades: RB92579, RB863129, RB867515 de cana-deaçúcar (Saccharum sp.), considerando-se a reprodução do nematóide, desenvolvimento das plantas e anatomia das raízes, com ênfase a diferenças na deposição de lignina e proporções do córtex e cilindro vascular. As avaliações foram efetuadas 90 dias após a inoculação com 5000 ovos de $M$. incognita por planta. Em relação à testemunha, Coda Radimax reduziu significativamente o número final de ovos por sistema radicular em todas as variedades. Coda Humus-PK e Coda Vit se mostraram eficientes em diminuir a densidade de ovos em RB867515, mas não em RB863129. Todos os compostos testados não afetaram o diâmetro do colmo, peso da biomassa seca da parte aérea e número de perfilho. Coda Radimax aumentou significativamente o 
número de colmos em RB92579 e a biomassa fresca da parte aérea em RB863129 e RB92579. Coda Humus-PK aumentou significativamente a altura da planta em RB92579 e a biomassa fresca da parte aérea em RB92579 e RB867515, enquanto Coda Vit afetou, significativamente, a biomassa fresca da parte aérea e raízes de RB863129. Fundamentando-se nas sessões transversais obtidas das raízes de cada variedade de cana observada sob microscópio ótico, não ocorreram modificações anatômicas significativas nos tecidos inoculados com $M$. incognita em relação aos tecidos sadios.

\section{REFERENCES}

Armstrong, W. (1979), Aeration in higher plants. Advances in Botanical Research, 7, 225-332.

Armstrong, W; Beckett, P. M. (1987), Internal Aeration and the Development of Stelar Anoxia in Submerged Roots. A Multishelled Mathematical Model Combining Axial Diffusion of Oxygen in the Cortex with Radial Losses to the Stele, the Wall Layers and the Rhizosphere. New Phytologist, 105, 221-245.

Benato, E. A. (2002), A indução de resistência no controle de doenças pós-colheita: frutas e hortaliças. Reunião Brasileira sobre Indução de Resistência em Plantas a Fitopatógenos, 1, 29-31.

Brandão, R. P. (2006), Fosfito estimula a autodefesa de plantas contra doenças fúngicas. Informativo Grupo Bio Soja, 3, 4-5.

Carlquist, S. (1990), Comparative wood anatomy: systematic, ecological and evolutionary aspects of dicotyledons wood. Taxon, 39(1), 67-68.

Chaves, A.; Pedrosa, E. M. R.; Guimarães, L. M. P.; Maranhão, S. R. V.; Silva, I. L. S. S.; Moura, R. M. (2004), Indução de resistência a Meloidogyne sp. em cana-de-açúcar cultivada em solo de áreas que apresentam declinio de desenvolvimento em tabuleiros nordestinos. Anais do Congresso Brasileiro de Fitopatologia, 37, 142.

Chaves, A.; Pedrosa, E. M. R.; Moura, R. M. (2002), Efeitos da aplicação de terbufos sobre a densidade populacional de fitonematóides endoparasitos em 5 variedades de cana-de-açúcar prevalentes no Nordeste. Nematologia Brasileira, 26(2), 167-176.

Chona B.L. (1950), Studies on the diseases of sugarcane in India. III. Sources and modes of red rot infection. Industrial Journal Agriculture Science, 20, 363-385.

Cohen, M. D.; Coffey, M. D. (1986), Systemic fungicides and the control of Oomycetes. Annual Review of Phytopathology, 24, 311-338.
Durrant, W. E.; Dong, X. (2004) Systemic acquired resistance. Annual Review of Phytopathology, 42, 185-209.

Frensch, J.; Steudle, E. (1989), Axial and radial hydraulic resistance to roots of maize (Zea mays L.). Plant Physiology, 91, 719-726.

Geelen, J. A. (1999), An evaluation of Agrio-Fos Supra 400 for the control of black spot and powdery mildew of apple in Hawke's Bay. N.I. :Geelen Research. Independent Horticultural Consulants.

Goller H. (1977), Beiträge zur anatomie adulter Gramineenwurzeln in Hinblick auf taxonomische Verwendbarkeit. Beiträge zur Biologie der Pflanzen, 53, 217-307.

Guest, D. I.; Bompeix, G. (1990), The complex action mode of action of phosphonates. Australasian Plant Pathology, 19, 113-115.

Hardy, G. E. St .J; Barret, S.; Shearer, B. L. (2001), The future of phosphate as a fungicide to control the soilborne plant pathogen Phytophthora cinnamomi in natural ecosystems. Australasian Plant Pathology, 30, 133-139.

Hussey, R. S.; Barker, K. R. (1973), A comparison of methodsfor colecting inocula of Meloidogyne spp. including anew technique. Plant Disease reporter, 57(12), 1025-1028.

Hussey, R. S.; Williamson, V. M. (1998), Physiological and molecular aspects of Nematode Parasitism. In: Plant and Nematode Interactions. Barker, K. R.; Pederson, G. A.; Windham, G. L. eds. Agronomy Monograph, 36, 87-108.

Jackson, T. J.; Burgess, T. ; Colquhoun, I.; Hardy, G. E. S. (2000), Action of the fungicide phosphite on Eucaliptus marginata inoculated with Phytophthora cinnamomi. Plant Pathology, 49, 147-154.

Julien, M. H. R.; Irvine, J. E.; Benda, G. T. A. (1988), Sugarcane anatomy, morphology and physiology. InDiseases of Sugarcane - Major Diseases, eds. B. T. Ricaud; A. G. JR. Egan; C. Gillaspie; C. G. Hughes, 1, 1-19.

Justin, S. H. F. W.; Armstrong W. (1987), The anatomical characteristics of roots and plant response to soil flooding. New Phytologist, 106, 465-495.

Krauter, D. (1985), Erfahungen mit Etzolds FSAFärbung für pflanzenschnitte. Mickrocosmos, 74, 231-233.

Maciel, S. L.; Ferraz, L. C. C. B. (1996), Reprodução de Meloidogyne incognita raça 2 e de Meloidogyne javanica em oito espécies de plantas medicinais. Science Agricola, 53(2-3), 232-236.

McDonald, M. P.; Galwey, N. W.; Colmer, T. D. (2002), Similarity and diversity in adventitious root anatomy as related to root aeration among a range of wetland and dryland grass species. Plant, Cell and Environment, 25, 441-451. 
Moura, R. M.; Pedrosa, E. M. R.; Maranhão, S. R. V. L.; Macedo, M. E. A.; Moura, A. M.; Silva, E. G.; Lima, R. F. (2000), Ocorrência dos fitonematóides Pratylenchus zeae e Meloidogyne spp. em cana-deaçúcar no Nordeste do Brasil. Fitopatologia Brasileira, 25, 101-103.

Niklas, K. J. (1992), Plant Biomechanics: An Engineering Approach to Plant Form and Function. University of Chicago Press, Chicago.

Niklas, K. J. (1999), Variations of the mechanical properties of Acer saccharum roots. Journal of Experimental Botany, 50, 193-200.

Novaretti, W. R. T.; Carderan, J. O.; Strabelli, J.; Amorim, E. (1989), Efeitos da utilização de composto, associado ou não a nematicida e adubos minerais, no controle de fitonematóides e na produtividade de cana-de-açúcar. Nematologia Brasileira, 13, 93-107.

Oliveira, S. M. A.; Dantas, S. A. F. D.; Gurgel, L. M. S. (2004), Indução de resistência em doenças pós-colheita em frutas e hortaliças. Revisão Anual de Patologia de Plantas, 12, 343-372.

Pedrosa, E. M. R.; Hussey, R. S.; Boerma, H. R. (1996), Penetration and post-infectional development and reproduction of Meloidogyne arenaria races 1 and 2 on susceptible and resistant soybean genotypes. Journal of Nematology, 28, 343-351.

Reich, P. B.; Uhl, C.; Walters, M. B.; Ellsworth, D. S. (1991), Leaf lifespan as a determinant of leaf structure and function among 23 tree species in Amazonian forest communities. Oecologia, 86, 1624.

Rickard, D. A. (2000), Review of phosphorus acid and its salts as fertilizer materials. Journal of Plant Nutrition, 23(2), 161-180.

Rosa, R.C.T. (2003), Estudo sobre o uso do nematicida carbofuran e de espécies de Crotalaria no controle de fitonematóides de cana-de-açúcar no Nordeste. PhD Thesis, Universidade Federal Rural de Pernambuco, Recife, Brazil.
Silva, L. H. C. P.; Resende, M. L. V. (2001), Resistência induzida em plantas contra patógenos. InManejo integrado de doenças e pragas em hortaliças, eds. L. H. C. P. Silva; J. R. Campos; G. B. A. Nojosa.

Taylor, A. L.; Sasser, J. N. (1978), Biology, identification and control of root-knot nematodes (Meloidogyne species). Ed. Raleigh: International Meloidogyne Project, NCSU and USAID Coop. Publ.

Vasellati, V.; Oesterheld, M.; Medan, D.; Loreti, J. (2001), Effects of Flooding and Drought on the Anatomy of Paspalum dilatatum. Annals of Botany. 88, 355-360.

Visser, E. J. W.; Colmer, T. D.; Blom, C. W. P. M.; Voesenek, L. A. C. J. (2000), Changes in growth, porosity, and radial oxygen loss from adventitious roots of selected mono- and dicotyledonous wetland species with contrasting types of aerenchyma. Plant, Cell and Environment, 23, 1237-1245.

Wicks, T. J.; Margarey, P. A.; De Boer, R. F.; Pegg, K. G. (1990), Evaluacion del fosfitopotasico como fungicida en Australia . Anais da Conferencia de Brighton para La Proteccion de Las Cosechas Pestes $Y$ Enfermedades, 1, 19-25.

Wilcox, T. P., Zwickl, D. J., Heath, T. A.; Hillis, D. M. (2002), Phylogenetic relationships of the dwarf boas and a comparison of Bayesian and bootstrap measures of phylogenetic support. Molecular Phylogenetics and Evolution, 25, 361-371.

Yin, Z.; Hoy, J. W. (1988), Effects of Oxygen Deprivation and Pythium Root Rot on Sugarcane Red Rot. Plant Disease, 82(11), 1237-1241.

Received: April 23, 2007; Revised: June 19, 2008; Accepted: April 29, 2009. 